\title{
Kleingärten - um componente da infraestrutura urbana: aspectos urbanísticos, ecológicos e sociais dos jardins arrendados na Alemanha
}

\author{
Allotment gardens - a component of green infrastructure: \\ allotment gardens in Germany and their urban, \\ ecological and social aspects
}

Carlos Smaniotto Costa

Doutorado em Arquitetura da Paisagem e Planejamento Ambiental pela Universidade de Hannover (Alemanha), professor, com atuação em ensino e pesquisa nos cursos de Pós-Graduação em Urbanismo da Universidade Lusófona em Lisboa, membro do Centro de Estudos do Território, Cultura e Desenvolvimento (Lisboa) e gerente-pesquisador da rede DialogUrban, Hannover - Alemanha, e-mail: smaniotto-costa@web.de

\section{Resumo}

O presente trabalho traz a conceituação dos chamados kleingärten, um sistema de jardins arrendados, presentes nas cidades alemãs, e enfoca o seu relevante caráter social, bem como o seu potencial na integração à infraestrutura de espaços verdes, como uma alternativa para melhorar a qualidade do ambiente urbano. Esses espaços, que poderíamos chamar de pulmões verdes, pertencem, na maioria dos casos, às prefeituras, que os arrendam a associações de pessoas que queiram plantar verduras, árvores frutíferas e flores. O movimento para a implementação desses jardins, sustentado por uma estrutura institucional, surgiu inicialmente para melhorar a qualidade de vida dos operários nas grandes cidades industriais. Hoje, quase 150 anos mais tarde, o movimento se transformou em uma manifestação cultural, por oferecer uma opção de lazer e recreação ao ar livre para uma boa parte da população e por ser um elemento marcante da paisagem urbana na Alemanha. Isso faz com que os kleingärten, pela sua natureza utilitária, seu interesse paisagístico e urbanístico e sua força política, justifiquem um estudo mais aprofundado.

Palabras-clave: Kleingärten. Alemanha. Jardins arrendados. Paisagem urbana. Espaços verdes.

\begin{abstract}
This paper discusses the concept of the kleingärten, a system of allotment gardens present in almost all German cities. It focuses on their social relevance and on their potential for building the green infrastructure, as a way to improve the quality of urban environment. These gardens, which could be called green lungs, are in most cases part of the city's real estate and leased to groups of people who want to grow vegetables, fruits and flowers. The movement of kleingärten, supported by a strong institutional framework, created these gardens initially to help workers in large industrial cities to increase food security and improve outdoor leisure opportunities, insuring an improvement in their quality of life. Today, almost 150 years later, the movement has become a
\end{abstract}


significant part of German culture. Offering leisure and outdoor recreation opportunities for a large part of the population kleingärten became a striking element of the urban landscape in Germany. Due to the leisure opportunities, landscape and urban significance and political force the kleingärten movement is interesting for gaining a deeper insight.

Keywords: Kleingärten. Germany. Allotment gardens. Urban landscape. Green spaces.

\section{Motivação e considerações preliminares}

Este artigo discorre sobre os kleingärten - o sistema de jardins arrendados presente em todas as cidades alemãs. Como não há uma expressão correspondente em português, prefiro manter neste artigo o termo em alemão: kleingarten e, no plural, kleingärten ${ }^{1}$. Alguns países onde também não existem expressões que transportem o conceito dos kleingärten adotam igualmente o termo em alemão. Os japoneses, ao importarem a ideia dos kleingärten, também não encontraram na sua língua um vocábulo adequado e, por isso, adotaram o termo em alemão.

Muitos brasileiros, ao passearem por cidades alemãs, se admiram com esse fenômeno comum em todo o país: grandes áreas verdes, diferentes de parques, ao longo das ferrovias ou autoestradas. As suas pequenas construções chamam a atenção entre as densas áreas habitacionais. Muitos acham, a princípio, tratar-se de algo semelhante a barracos ou favelas e se surpreendem ao descobrir que são jardins e hortas arrendados.

Os kleingärten são um elemento importante da cultura alemã, com inestimáveis valores urbanísticos, sociais e ecológicos. Como menciona Gröning (2006, p. 155), com o movimento kleingärten, a Alemanha prova, há mais de cem anos, que jardinagem numa associação pode ser uma poderosa faceta política e social na cultura urbana.

Como professor de paisagismo e de ecologia urbana, ocupo-me principalmente dos espaços livres e das interdependências entre esse espaço e o construído no ambiente urbano. E isso não só do ponto de vista ecológico-ambiental, mas também pelo aspecto recreativo e da interação social; da maneira como as pessoas se apoderam do espaço para atividades diárias e de lazer. Pela maneira como uma sociedade usa os espaços públicos e as suas razões para tal, cria-se o que chamo de cultura de uso.

Segundo dizem, os alemães, pelos seus invernos rigorosos, têm um prazer imenso em estar draußen - ao ar livre. E passar o tempo fora de suas casas significa, para muitos, cuidar de um canteiro e gozar a sombra dos jardins e parques.

\section{Compreendendo a essência dos kleingärten}

Literalmente, o termo kleingarten significa "pequeno jardim". Dependendo da região na Alemanha, outros termos como Schrebergarten, Familiengarten ou Heimgarten são usados. É importante observar que não se trata de hortas comunitárias, o que também existe na Alemanha, porém com menos incidência.

A Alemanha dispõe de uma longa tradição na cultura do jardim e do espaço livre (GRÖNING, 2006), e isso se reflete não só na busca de espaços ao ar livre para atividades de lazer e recreação, mas é também um importante fator urbanístico e econômico (BUNDESMINISTERIUM FÜR VERKEHR, BAU UND STADTENTWICKLUNG - BMVBS, 2008; SMANIOTTO COSTA, 2008; GALK, 2005). Calcula-se que o setor da indústria de móveis de jardim, de ferramentas e utensílios de jardinagem, plantas e viveiros movimentou em 2011 pelo menos 16 bilhões de euros. 0 setor se encontra em alta e vive seu melhor momento na história recente (THIMM, 2011). 0 setor de meio ambiente como um todo vive um boom na Alemanha, com forte tendência de bater novos recordes nos próximos anos. Uma boa parte deste boom advém da manutenção de jardins e dos kleingärten.

Os Kleingärten são, há décadas, um importante componente da paisagem urbana do país (Figura 1).

\footnotetext{
1 No singular pronuncia-se "klaingarten", e no plural kleingärten, "klaingérten".
} 
Hoje existem em toda a Alemanha mais de um milhão de kleingärten, cobrindo uma área de mais de 46 mil hectares. Eles estão presentes, embora com pequenas variações formais ou locais, em todas as cidades alemãs (BUNDESVERBAND DEUTSCHER GARTENFREUNDE - BDG, 2011). Cinco milhões de pessoas os usam para atividades quotidianas de lazer (BMVBS, 2008; GALK, 2005).

A Alemanha não mantém o monopólio em kleingärten. Eles podem ser encontrados em diversos países europeus, com maior ou menor incidência, sendo, no entanto, mais comuns na Europa Central e Escandinávia. Somente a título de ilustração: os kleingärten encontram seus correspondentes em kolonihave, na Dinamarca, koloniserade trädgårdar, na Suécia, jardin familiaux, na França; na Holanda e Bélgica, são chamados de volkstuin, e na Inglaterra, de allotment garden. No sul da Europa são encontrados com menos frequência. Na Espanha ou Itália, por exemplo, parecem ser totalmente desconhecidos. Em Lisboa, Portugal, foram criados os primeiros lotes chamados de hortas urbanas - em outubro de 2011.

Ainda há muita discussão sobre em que país os kleingärten surgiram primeiro - fato difícil de ser comprovado. Mas já em 1926 é fundada em Luxemburgo a confederação internacional Office International du Coin de Terre et des Jardins Familiaux (2011), que engloba as federações nacionais de 14 países e defende

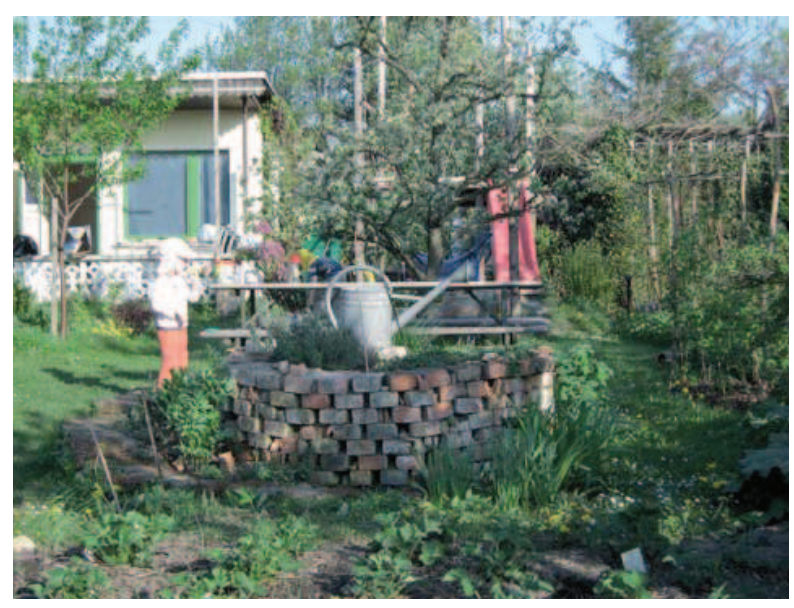

Figura 1 - Um kleingarten na colônia Rudolphia, criada em 1902 na cidade de Dresden

Foto: Lutz Reiter (2010). os interesses de 3 milhões de arrendatários. Em 2006, a federação japonesa firmou a sua adesão.

\section{Método de pesquisa e objetivos}

Este trabalho é essencialmente baseado em um levantamento feito no âmbito do projeto GreenKeys (Urban Green as a Key for Sustainable Cities). Esse projeto - financiado pela Comunidade Europeia teve como uma de suas finalidades desenvolver uma metodologia para a implementação de estratégias voltadas ao desenvolvimento de espaços verdes.

No intuito de obter uma visão geral sobre a tipologia de áreas verdes existentes na Europa, foi realizado um levantamento, não só junto àquelas cidades diretamente envolvidas no projeto, como também em várias outras cidades. Por meio de uma coleta estruturada, foram levantados dados sobre cada tipo de espaço, suas características, potencialidades, benefícios e problemas.

Esse levantamento, por sua vez, criou um imenso conjunto de ideias e possibilidades, o que levou à criação de um "banco de ideias", o chamado Pool for Strategies, além do inicialmente previsto e-Learning Module. 0 e-Learning Module é uma apresentação preparada para promover a ideia de desenvolver estratégias para a gestão urbana, tendo como destinatários primários aqueles profissionais que tomam decisões que influenciam o planejamento urbano (por exemplo: políticos, urbanistas, construtores de ruas e estradas), mas carecem de informações mais profundas sobre os valores e benefícios que os espaços verdes podem trazer ao ambiente urbano. Mais informações sobre o projeto GreenKeys e os seus resultados podem ser obtidos no site do projeto ${ }^{2}$.

\section{As características dos kleingärten e das kleingartenkolonien}

Um kleingarten é, por definição legal, um espaço destinado ao lazer e à recreação ao ar livre e para oferecer a possibilidade às famílias de cultivarem frutas e legumes (GALK, 2005). Os kleingärten são formados, a princípio, por várias unidades ou parcelas,

\footnotetext{
2 No site do projeto estão à disposição, além do manual GreenKeys @ your city, os instrumentos desenvolvidos, bem como o Pool for Strategies, e o e-Learning Module mencionados (GREENKEYS, 2008).
} 
arrendadas por tempo indeterminado. 0 conjunto de parcelas em um determinado local forma o que em alemão é denominado de colônia (Kolonie ou Kleingartenkolonie) (Figura 2). As parcelas devem somente ser usadas para recreação e para a produção própria de alimentos, isto é, elas não podem ser usadas para uma produção comercial.

Os kleingärten são encontrados principalmente em áreas urbanas e periurbanas, já que a população dessas áreas é geralmente aquela mais afetada pela escassez de espaços livres e áreas propícias ao lazer ao ar livre. Normalmente, os kleingärten estão instalados em terrenos públicos ou de entidades autárquicas. $\mathrm{Na}$ cidade de Hannover, por exemplo, 75\% dos kleingärten estão instalados em áreas comunais (BDG, 2011).

É muito comum encontrá-los em áreas não edificáveis, como nas faixas de domínio de ferrovias e rodovias ou junto ao leito de rios ou lagos. Esses terrenos são cedidos às associações, que, por sua vez, fazem o parcelamento e os arrendam a interessados. Cada colônia deve ser composta, além das várias parcelas, por áreas de uso comunitário, como as vias internas, playgrounds e a sede da associação. Muitas têm ainda um espaço para festas, estacionamentos etc. Todos os arrendatários são obrigados a prestar uma quantidade de horas de trabalho para fins comunitários, como para a manutenção das áreas comuns ou a organização de eventos. A quantidade de horas, bem como o tipo de serviço, varia em cada associação, cabendo ao conselho a organização dessa tarefa. Evidentemente, existem exceções e isenção para pessoas incapacitadas. Algumas associações cobram uma taxa de indenização por horas

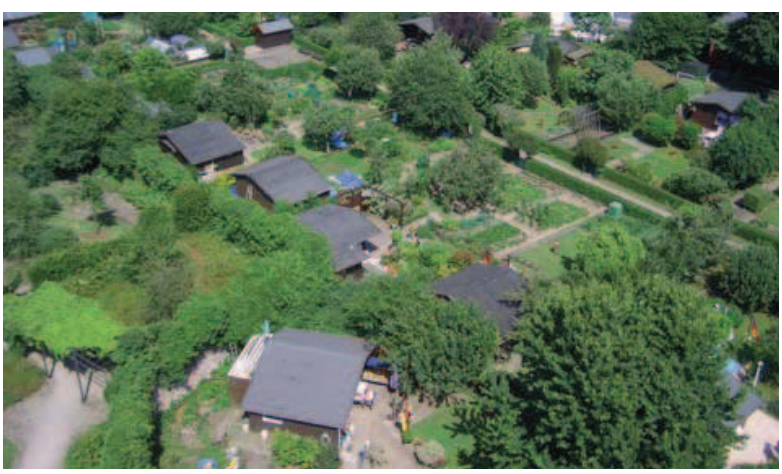

Figura 2 - Vista da colônia Am Wasserturm, na cidade de Mühhheim Nota: Aqui, percebe-se a estrutura das parcelas, com os seus gazebos e as áreas comuns de circulação.

Foto: SMANIOTTO COSTA, 2008. não trabalhadas e não justificadas; em Hannover são, em média, 25 euros/hora (HARBART, 2011).

Os kleingärten podem ser parte integrante da infraestrutura verde pública. Assim, para gozar dos incentivos e da proteção da lei, as colônias devem permitir o livre acesso da população às áreas comuns. Os portões principais devem estar abertos das 8 às 18 horas. Em muitos casos, a sede da associação também funciona como bar/restaurante, o que aumenta a atratividade.

0 tamanho de uma parcela deve estar entre 200 e $400 \mathrm{~m}^{2}$. Cada arrendatário se compromete a seguir e observar as leis e normas ambientais e de proteção da natureza, previstas nas leis estaduais e municipais. Algumas colônias vão além e, por exemplo, proíbem o uso de agrotóxicos, incentivando o controle biológico de pragas, ou estimulam o cultivo de variedades antigas de frutas e plantas ornamentais (GALK, 2005).

Nas parcelas somente é permitido o mínimo necessário de pavimentação e uma construção simples de, no máximo, $24 \mathrm{~m}^{2}$ de área total. Essa construção, uma espécie de gazebo, chamado de Laube, tem como finalidade principal guardar ferramentas de jardinagem. Pelas suas características, equipamentos e instalações, o gazebo não pode ser adequado para uma habitação permanente (Figura 3). Assim, um kleingarten não deve ser usado como substituto de uma moradia. Alguns kleingärten permitem que os arrendatários pernoitem nos fins de semana. Porém, tanto este aspecto quanto a metragem máxima construída, sem uma inspeção rigorosa, é de difícil controle.

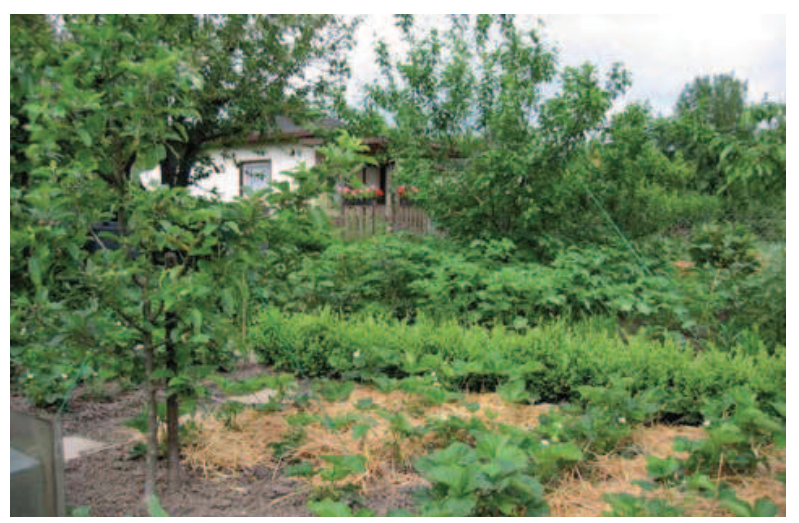

Figura 3 - Uma típica parcela de kleingarten em Dresden, onde se vê a plantação de hortalicas e árvores frufifferas e 0 gazebo da parcela vizinha Fonte: BARBARA SCHÖN, 2011. 
Para não facilitar o uso permanente, ou para coibir a moradia fixa, muitos kleingärten não estão ligados às redes de água tratada nem de esgotos, o que torna o seu uso diário menos cômodo. Nesses casos, se usa a fossa séptica e água de poços artesianos. $\mathrm{Na}$ cidade de Hannover está também proibida a instalação de telefones ou antenas de qualquer espécie, bem como de máquinas de lavar pratos ou roupas (STADT HANNOVER, 2004b). A manutenção de cada parcela está a cargo do seu arrendatário. A contratação de terceiros para este serviço não é permitida.

0 valor médio que um arrendatário paga por ano pela sua parcela é 276 euros, com extremos que variam bastante. Nas grandes cidades, esse valor pode subir até 450 euros. Em média, outros 190 euros são gastos em plantas, sementes, ferramentas, materiais de construção, livros e revistas sobre jardinagem (BMVBS, 2008).

$\mathrm{Na}$ cidade de Hannover, a taxa de arrendamento de um kleingarten está na faixa de 250 a 300 euros anuais. Além disso, o arrendatário também deve arcar com outras taxas (luz e água). Muitas vezes, quando o novo arrendatário assume uma parcela, este tem que ressarcir as benfeitorias feitas pelo antecessor, como, por exemplo, a construção do gazebo, a pavimentação ou mesmo as árvores e plantas ornamentais. Muitas vezes, porém, acontece o contrário: quando a parcela estiver muito descaracterizada, o arrendatário atual deve indenizar o novo. Normalmente, a federação regional faz um levantamento da situação e uma estimativa dos custos. Em geral, calcula-se o valor de entre 2 mil e 4 mil euros como indenização pelas benfeitorias em uma parcela (HARBART, 2011).

Somente é permitido plantar árvores frutíferas, restringindo-se o plantio àquelas de porte pequeno ou médio. Outras espécies arbóreas estão proibidas. Árvores frondosas, quando encontradas em alguma colônia, são muito provavelmente remanescentes de usos passados. A proibição se deve, primeiro, a um fator histórico, já que as espécies não frutíferas não são compatíveis com a ideia de plantar o seu próprio alimento, e, segundo, porque as árvores na Alemanha, acima de um determinado porte, estão automaticamente protegidas por lei (as frutíferas estão excluídas desta proteção). Árvores sob proteção poderiam dificultar uma modificação no uso da área. Com o tempo, a criação de animais tornou-se incômoda e indesejada e está proibida na maioria dos kleingärten. Em algumas colônias, exceções são feitas para a criação de abelhas para a produção de mel.

Outra característica dos kleingärten está ligada à educação, pois todas as federações regionais oferecem, além de uma diversificada literatura de apoio, cursos de formação e treinamento, que abrangem os mais diversos temas relacionados à jardinagem, ecologia, uso de plantas endêmicas, proteção ambiental, questões jurídicas e relações públicas.

Dentro das colônias está proibido o uso de veículos motorizados de qualquer natureza, porém a bicicleta é permitida. Muitas pessoas alheias às colônias usam as vias internas para encurtar seu trajeto, o que pode gerar conflitos. 0 tráfego de ciclistas em "alta velocidade" é a causa mais citada pelos arrendatários em reclamações (GALK, 2005).

\section{Estrutura institucional}

A característica principal de um kleingarten é a sua organização, sendo a associação dos arrendatários a representação máxima de uma comunidade. As associações, por sua vez, estão organizadas em 20 confederações regionais e na poderosa Federação Alemã dos Amigos dos Jardins (Bundesverband Deutscher Gartenfreunde - BDG), fundada em 1921, e que representa as 15 mil associações existentes atualmente.

Cada associação é dirigida por um conselho eleito entre os arrendatários, sendo todas elas sem fins lucrativos. Cada uma cria as suas regras de convivência e rege por meio de um estatuto. Dentre as tarefas da associação estão a concessão das parcelas e o controle do seu uso. 0 estatuto, assim como a própria colônia em si, não pode, porém, colidir com os dispositivos da Lei Federal de 1983, que rege o sistema Kleingärten (Bundeskleingartengesetzt). Daí pode-se deduzir a importância dos kleingärten, já que uma lei federal dispõe sobre as regras gerais e a sua utilidade pública, além de disciplinar a questão dos contratos de arrendamento e da integração dos kleingärten ao planejamento urbano. A lei de urbanização alemã (Baugesetzbuch), também federal, permite às cidades estabelecer kleingärten como uso permanente do solo (BUNDESMINISTERIUM DER JUSTIZ - BMJ, 2011a, b). Para tanto, essas áreas devem ser sinalizadas nos planos diretores e estabelecidas nos planos de uso do solo e planos de pormenor. Para que esse 
caráter seja permanente, é necessário que o proprietário do terreno esteja de acordo.

Essa proteção, porém, nem sempre é permanente. Não raro, os kleingärten têm que ceder seu espaço para construções ou para a ampliação de infraestruturas. Esse tipo de conflito tende a agravar-se naqueles municípios que não possuem uma estratégia para a aquisição de terrenos, podendo chegar às vezes até o protesto político organizado (GRÖNING, 2006). Ao contrário, também existem outros casos em que a razão para a proteção permanente de certas colônias tenha sido em função da influência política de suas associações.

$\mathrm{Na}$ Alemanha, ao contrário da maioria dos outros países, a rescisão de um contrato de arrendamento entre uma colônia e o proprietário do terreno é uma tarefa árdua e cara, mesmo que seja de comum acordo (STADT HAMBURG, 2007). A lei federal Bundeskleingartengesetzt determina que o proprietário coloque à disposição da associação uma área substituta com qualidades semelhantes àquela que essa deve deixar e indenize todos os benefícios existentes. Tal proteção jurídica permite que nos kleingärten na Alemanha haja mais investimentos tanto por parte da associação em equipamentos comunitários como dos arrendatários nas suas parcelas (BDG, 2011).

Muitos kleingärten têm regras rígidas para a manutenção e composição das parcelas; dispõem, por exemplo, sobre a proporção entre áreas destinadas ao plantio de hortaliças e plantas ornamentais, quais espécies de plantas podem ser usadas, sobre a cor das cercas, a quantidade de árvores frutíferas ou a que altura as cercas vivas devem ser mantidas. A regra geral dita que pelo menos um terço da parcela deve ser usado como horta (GALK, 2005). A questão da produção de verduras e hortaliças é questionada atualmente, já que adquiri-las no supermercado, além de sair mais barato, é, para muitos, também mais cômodo. Outro conflito é visto no "crescimento" de áreas gramadas. Esse tipo de cobertura vegetal não estava previsto na ideia original dos kleingärten, mas hoje são importantes para a recreação, principalmente de crianças (GALK, 2005).

Para muitos, essas regram interferem em demasia na esfera pessoal, extrapolando os limites do bom senso. Essas regras rígidas e imposições inflexíveis, aliadas a um controle rigoroso pelos membros do conselho, criaram com o tempo a imagem estereotipada dos arrendatários de kleingärten como conservadores e pedantes. Essa postura assustou, por muito tempo, potenciais usuários mais jovens.

Num período em que o Estado cada vez mais se afasta das suas atribuições sociais, os kleingärten podem assumir um importante papel nesta esfera. Para tanto, as associações exigem de muitas cidades a garantia de sua existência e reconhecimento como parte da infraestrutura urbana. 0 próprio estudo do BMVBS (2008) levanta a questão se a lei federal que dispõe sobre os kleingärten ainda é necessária. A resposta dos entrevistados foi unânime em favor de sua manutenção, já que somente ela pode garantir que o sistema Kleingärten possa manter e expandir plenamente as suas funções urbanísticas, sociais e ecológicas, além de garantir a própria existência dos kleingärten como uma importante herança cultural.

\section{A dimensão dos kleingärten e a sua influência sobre o ambiente urbano}

Pela sua importância social, os kleingärten assumem um relevante papel em todas as camadas da sociedade alemã, já que há arrendatários provenientes de todas as classes sociais (GALK, 2005). Em relação ao planejamento urbano e ao meio ambiente, a sua característica essencial está na sua contribuição para a arborização e para abrandar os efeitos negativos das áreas construídas no ambiento urbano. Efeitos de sinergia surgem quando os kleingärten estão conectados a outros espaços naturais, ampliando ou criando corredores verdes, como demonstram as Figuras 4 e 5 da cidade de Dresden.

Como área de lazer, eles atuam como um substituto à falta de outros espaços verdes vicinais. Ainda hoje, em muitos bairros, as colônias são o único grande espaço verde disponível. A maioria das colônias mantém playgrounds nas suas áreas comunitárias, muitas vezes longe do perigo e dos ruídos provocados pelo tráfego.

O levantamento feito em 2008 revelou que existem na Alemanha cerca de 1.240 .000 parcelas de kleingärten, cobrindo uma área de mais de 46.000 hectares (BMVBS, 2008). Além disso, há uma estimativa de outras 150.000 parcelas espalhadas pelo país, que estão organizadas de formas diferentes ou, em parte, nem mesmo organizadas. 


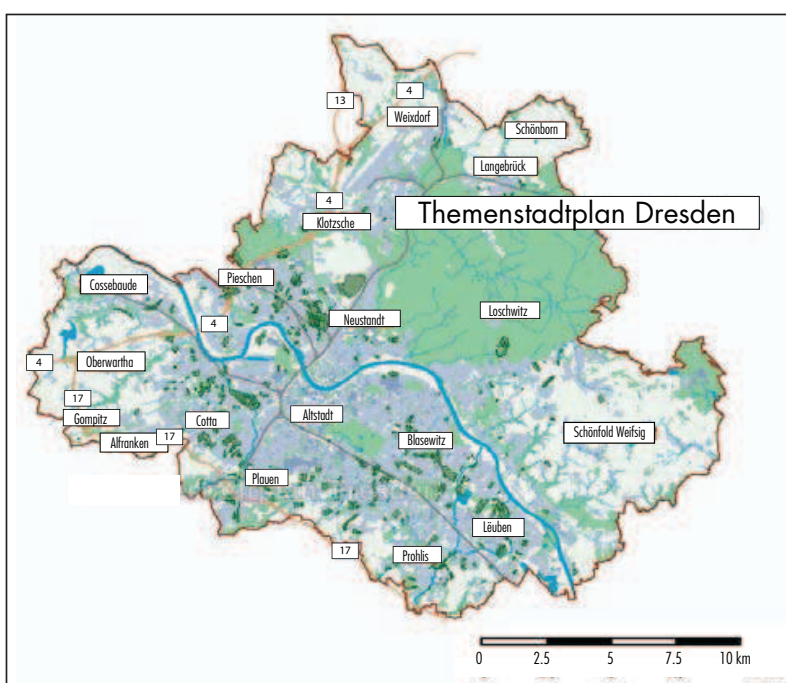

Figura 4 - Mapa temático gerado pelo Serviço de Urbanismo do Município de Dresden contendo as subprefeituras e as 366 colônias de kleingärten Fonte: STADT DRESDEN, 2012.

Nota: Na cidade existem 23.428 parcelas cobrindo um total de 763,9 ha.

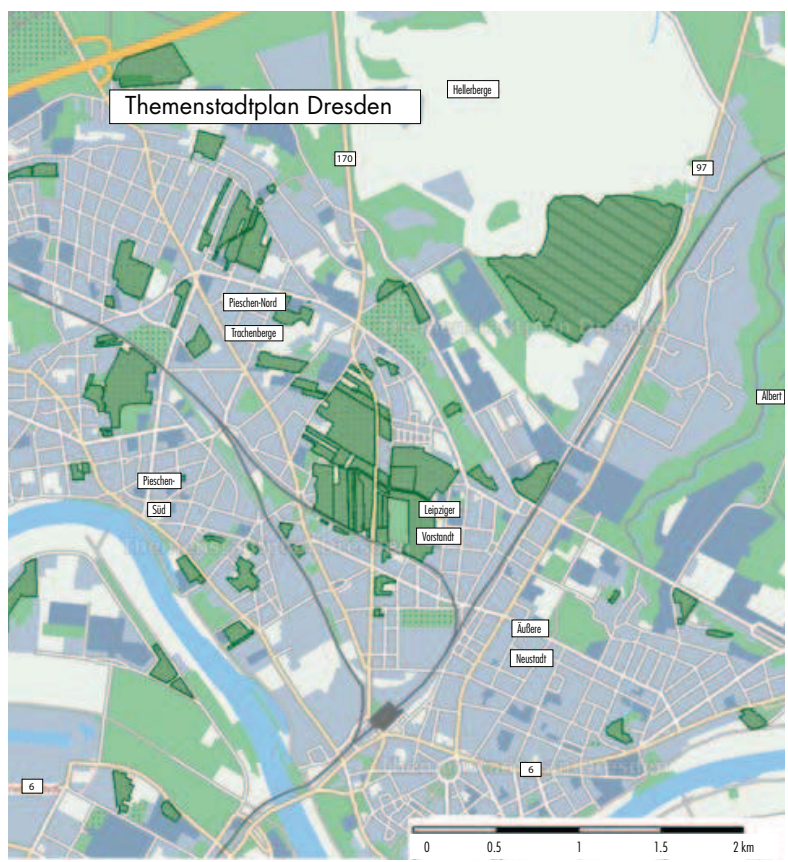

Figura 5 - Pormenor da região noroeste da cidade de Dresden, com as colônias de kleingärten

Fonte: STADT DRESDEN, 2012.
0 estudo também revela que mais de cinco milhões de pessoas usam os kleingärten para suas atividades quotidianas de lazer (BMVBS, 2008), número que não considera aqueles que usam os kleingärten indiretamente como amigos ou conhecidos de arrendatários ou aquelas pessoas que os utilizam para um simples passeio. Além disso, outros 100 mil voluntários trabalham em atividades relacionadas aos kleingärten (BMVBS, 2008). Sem eles, a ideia dos kleingärten como uma entidade comunitária não poderia ser realidade. Dentre outras atividades, eles fazem treinamentos e dão assistência social, técnica e jurídica aos associados, atuando como um importante elo entre a sociedade e as associações.

Segundo BDG (2011) e BMVBS (2008), a idade média dos arrendatários é de 60 anos, e grande parte deles são aposentados; $94 \%$ dos arrendatários de kleingärten moram em prédios de apartamentos, sem disponibilidade de jardins. Em média, as parcelas ficam arrendadas por 19 anos, e 1 em cada 5 por mais de 30 anos.

Na questão da distância entre a moradia do arrendatário e o kleingarten, o estudo do BMVBS (2008) constatou que $84 \%$ dos kleingärten se encontram em um raio de mais de cinco quilômetros de distância; 96\% dos arrendatários precisam de, no máximo, meia hora para ir até a sua parcela, enquanto $60 \%$ gastam menos de 15 minutos a pé ou menos de bicicleta (os dois modos mais comuns usados para o deslocamento). A distância entre a residência do arrendatário e a parcela é um fator importante. Todos buscam uma parcela onde se possa ir sem uma "perda substancial de tempo" ou sem a necessidade de enfrentar tráfego, já que, principalmente no verão, muitos arrendatários usam os kleingärten diariamente, principalmente no final da tarde, depois de um dia de trabalho.

A despeito das diferenças regionais, os kleingärten são encontrados em todas as cidades alemãs (BDG, 2011). 0 estudo do BMVBS (2008), porém, revelou que existem grandes diferenças regionais no que se refere ao tamanho das cidades ${ }^{3}$. Os kleingärten são mais frequentes nas cidades grandes que

\footnotetext{
${ }^{3}$ Na Alemanha não existe uma definição legal no que tange à classificação das cidades segundo o número de habitantes. Estatisticamente é usada a seguinte escala: cidade-rural (menos de 5 mil hab.), cidade pequena (menos de 20 mil), cidade média (menos de 100 mil), cidade grande (acima de 100 mil) e metrópole (com mais de um milhão de hab.). Muitas vezes, as cidades grandes são distinguidas entre cidade grande "pequena" com uma população entre 100 mil a 300 mil hab. e a cidade grande "grande" com uma população acima dos 300 mil hab. As estatísticas apontavam em 2010 três metrópoles (Berlim, Hamburgo e Munique) e 80 cidades grandes; em 2006 eram 82 (STATISTISCHES BUNDESAMT DEUTSCHLAND, 2010).
} 
naquelas médias ou pequenas. Tomando como parâmetro a quantidade de kleingärten em relação à população (densidade de kleingärten), a análise da BDG (2011) nas 15 maiores cidades do país evidenciou esta disparidade. Em média existem 2,0 parcelas para cada 100 habitantes - mas com extremos que variam de 6,2 na cidade de Leipzig (12 $2^{\mathrm{a}}$ maior cidade e berço dos kleingärten) e 0,6 em Munique, a terceira cidade mais populosa do país ${ }^{4}$. Na capital alemã, Berlim, a média é de 2,0 parcelas para cada 100 habitantes. No total, só a capital conta com 74 mil parcelas agrupadas em 934 associações.

Na cidade de Hannover ${ }^{5}$, com uma média de 3,2, havia em 2009, segundo os dados da cidade, 20.370 parcelas, das quais 14.455 se encontram em propriedades do município e organizadas em 270 colônias e em 102 associações. 0 número de parcelas subiu para algo acima de 21.000 em 2011. Das 102 colônias, 90\% têm caráter permanente, garantido pelo plano diretor. Essas parcelas cobrem o total de 1.009 ha, ou 5\% da área do município (STADT HANNOVER, 2004a), onde as colônias de kleingärten estão distribuídas como um cinturão verde ao redor do centro da cidade (Figura 6). Na cidade de Leipzig, as 278 colônias com 39 mil parcelas cobrem uma área de, aproximadamente, 1.240 ha, o que corresponde a $7 \%$ da área urbana e a 30\% do total de áreas verdes. Os kleingärten formam, assim, um dos principais componentes do pulmão verde da cidade (STADT LEIPZIG, 2011b).

Em média, as áreas comunitárias tomam de 14\% a $17 \%$ do total da área das colônias. Segundo o estudo do BMVBS (2008), um quarto de todas as associações tem uma sede construída, $60 \%$ delas dispõem de um espaço ao ar livre para festas e $50 \%$ de um playground.

Em muitas cidades, a prefeitura dá subsídios para a realização de projetos, para medidas visando à conservação do meio ambiente e da natureza, bem como para treinamento, relações públicas e comemorações importantes.

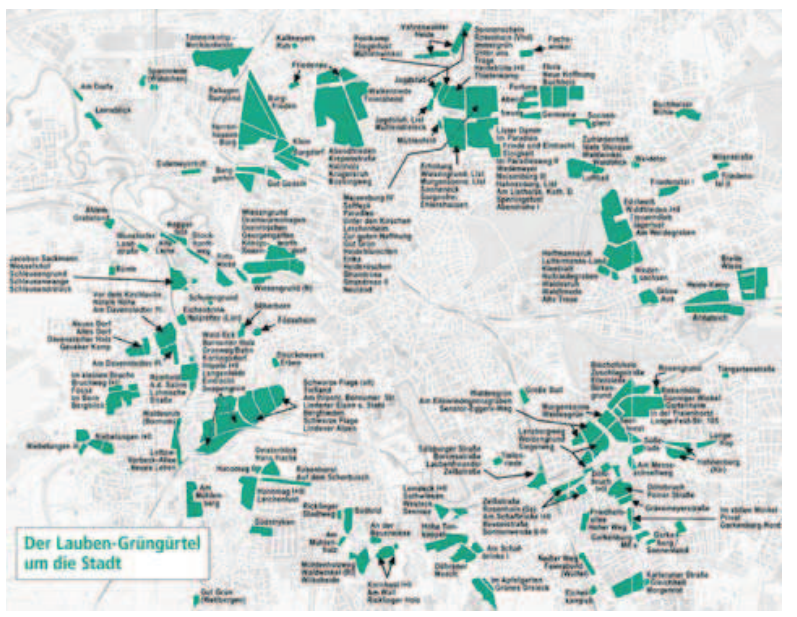

Figura 6 - Na cidade de Hannover, há atualmente mais de 21 mil unidades de kleingärten, agrupados em 270 colônias e organizados em 97 associações

Fonte: HARBART, 2011.

Considerando as parcelas em si, o estudo do BMVBS (2008) revelou que $36 \%$ da área de cada uma ainda é usada como horta, porém essa proporção vem decrescendo paulatinamente. De 1997 a 2008 , baixou de $40 \%$ aos $36 \%$ mencionados. Um gazebo é encontrado em $97 \%$ das parcelas, com uma média de $21,5 \mathrm{~m}^{2}$ de área construída, com tendência crescente. Em 1997, essa média era de $19 \mathrm{~m}^{2}$. Ainda assim, a média se encontra abaixo do total permitido. 0 seu uso também vem se modificando, deixando de ser um "quartinho" de ferramentas para se transformar em uma sala de estar. Outra tendência se refere ao número de prefeituras que aceitam a ligação das parcelas às redes de serviço público como água encanada, coleta de esgoto e energia elétrica: $88 \%$ das colônias já contam com água encanada. No entanto, dessas, somente $37 \%$ contam com água encanada nos gazebos. Todas as colônias já têm acesso à energia elétrica.

Em toda a Alemanha, o número de aficionados aos kleingärten cresce como nunca (BDG, 2011).

\footnotetext{
4 Na página da Wikipedia sobre os kleingärten está publicada a tabela sobre a relação entre a população e a quantidade de kleingärten nas 15 maiores cidades alemãs. Disponível em: <http://de.wikipedia.org/wiki/Kleingarten>. Acesso em: 25 abr. 2011.

5 A cidade de Hannover, com quase 50\% da área do município considerados espaços verdes, é conhecida como "a cidade dos jardins". Lá, o Departamento do Meio Ambiente e Espaços Verdes é responsável pelos kleingärten. No site deste Departamento há um banco de dados onde todo o tipo de informação sobre cada uma das colônias pode ser visto. Disponível em: <http://www.hannover.de/ de/umwelt_bauen/umwelt/nah_park/naherh/klgakult/índe.html>; <http://www.hannover-gis.de/GIS/?thema=6>. Acesso em: 4 jul. 2011.
} 
Nos últimos anos, a geração entre 25 e 40 anos está redescobrindo os kleingärten e, assim, segundo a BDG (2011), garantindo o seu futuro. Essa afirmação é questionável, se observarmos que na cidade de Hannover somente 20\% dos arrendatários têm crianças pequenas, o que corresponde à situação nacional. Na Alemanha, a proporção de famílias com crianças pequenas é de somente $23 \%$. Esse índice é alcançado principalmente porque as famílias de imigrantes têm mais filhos que as famílias alemãs (STADT HANNOVER, 2004a). Mesmo assim, a descoberta dos kleingärten pelos mais jovens vai contribuir para a redução da idade média dos arrendatários (Figura 7).

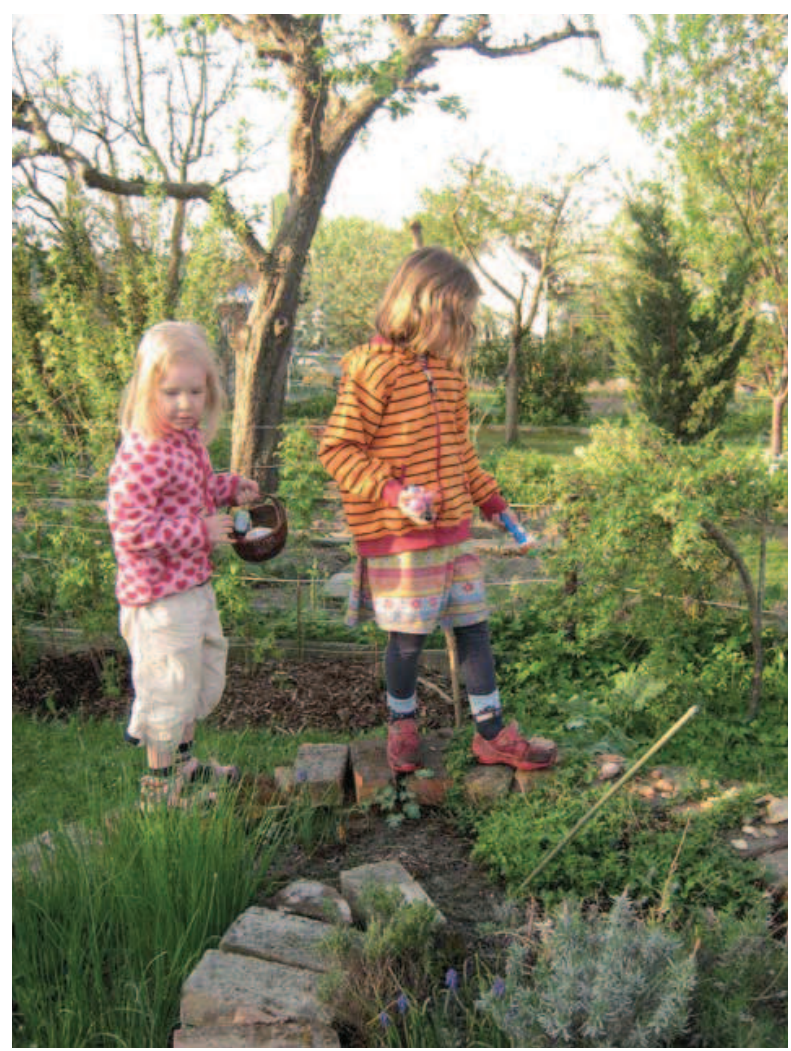

Figura 7 - As colônias de kleingärten muitas vezes têm que compensar a falta de playgrounds públicos

Foto: Lutz Reiter (2010).

Nota: Ao oferecer às crianças e adolescentes um espaço propício para aventuras, desperta 0 interesse por processos naturais e percepção pela natureza. Assim como todo espaço verde, os kleingärten nos dão uma lição de biologia.
A demanda por parcelas, principalmente nas grandes cidades, atualmente está excedendo a oferta; $40 \%$ das associações mantêm listas de espera, nos estados do leste, esse número sobe a $60 \%{ }^{6}$. Nas regiões caracterizadas pela redução da população, é possível encontrar algumas parcelas sem uso. Com essa intensa procura, muitas associações podem escolher os novos arrendatários, dando preferência àqueles que provavelmente seguirão mais tradicionalmente as normas das associações. Mas algumas estão mudando, e já aceitam candidatos com uma natureza mais "rebelde", onde a cerca viva não é mantida a exatamente $1,50 \mathrm{~m}$ de altura, nem a grama cortada todo o fim de semana.

Esse fenômeno também fornece um diagnóstico sociológico. Sociólogos veem a causa do boom dos kleingärten como uma reação aos efeitos da globalização e da crise econômica mundial. Para muitos, o mundo está se tornando complexo demais, criando um sentimento de perda, fazendo crescerem os anseios por valores familiares e tradicionais (BMVBS, 2008). Estar em um ambiente considerado natural, trabalhar a terra e cuidar do próprio alimento devolve a sensação de segurança. De acordo com Thimm (2011), os alemães veem os jardins como se fossem o único lugar seguro do mundo, como uma alternativa à agitação e mobilidade, um lugar onde as pessoas estão incólumes às ameaças de terrorismo, aos perigos de radiação e substâncias químicas.

\section{De um clube de pedantes a atores políticos}

Os kleingärten criam um espaço especial: geralmente situados no meio do aglomerado urbano, com localização privilegiada, eles oferecem tranquilidade e relaxamento; e se tornaram muito mais do que um oásis para os pequenos burgueses e amantes da natureza. Hoje, os kleingärten são também uma questão política, a qual não deve ser subestimada. Poucos políticos e administrações públicas ousam ir contra as associações, em razão de sua capacidade de mobilizar eleitores.

\footnotetext{
${ }^{6}$ No site da DBG funciona uma bolsa de parcelas. Disponível em: <http://www.kleingarten-bund.de>. Acesso em: 4 jul. 2011. Também em sites de comércio eletrônico são frequentes as ofertas de parcelas.
} 
Embora a maioria dos kleingärten tenha a sua existência garantida, há também exemplos que contestam essa garantia. A cidade de Hannover tem um plano (Kleingartenbedarfsplan), ainda da década de 1990, que tenta prever a futura demanda de parcelas e deliberar sobre possíveis locais para a instalação de novas colônias. Uma versão mais atual desse plano não existe, o que deixa acirrado o debate sobre a conversão de kleingärten em "áreas passivas para a construção". Como sempre, o interesse maior é o financeiro, já que os kleingärten estão muitas vezes bem localizados, com toda a infraestrutura disponível; e isso desperta interesses. Muitas cidades preferem não dar caráter definitivo aos kleingärten, fato que levanta questões que podem ser interpretadas como uma ameaça (BDG, 2011).

$\mathrm{Na}$ cidade de Hannover corre atualmente um processo de desapropriação de uma colônia, situada privilegiadamente junto a um grande bosque público. Um grupo imobiliário comprou a área de 45.000 $\mathrm{m}^{2}$, embora o plano diretor da cidade defina a área como de uso permanente para kleingärten, e na prefeitura não se veja a necessidade de modificar este status. Mesmo assim, os investidores vêm lutando para modificar o plano de uso do solo e para obter, a longo prazo, o direito de construir na área. Há um agravante que só veio à tona nos últimos dias: o grupo imobiliário faz parte do conglomerado de uma das grandes montadoras alemãs ${ }^{7}$, que é também a maior empregadora da cidade. Com isso, cresce o receio de que o poder de uma empresa deste porte mobilize a classe política e consiga a necessária alteração nos planos urbanísticos. Um forte argumento a favor da construção é o fato de que na frente da colônia passa uma linha de bonde, construída para conectar o centro da cidade à área da exposição universal, que a cidade sediou em 2000 (Figura 8).

É uma briga acirrada, e que divide não só as duas partes diretamente envolvidas, mas também os partidos políticos - enquanto a esquerda e o Partido Verde são contra a modificação, os partidos conservadores e da direita estão a favor. "É estranho e surpreendente que um kleingarten, depois da mudança de proprietário, possa ser simplesmente destruído, embora oficialmente não haja intenção de alterar o atual plano de uso do solo" - com esta frase, o
Partido Socialista Alemão (SPD) manifesta o apoio à permanência desse kleingarten. Essa disputa tem um agravante: o prefeito da cidade é deste partido, mas o Partido Democrata Cristão está no governo estadual. Essa disputa ainda vai demorar muito até ser resolvida, podendo causar um desgaste político.

\section{Kleingärten e o verde urbano como um paliativo e uma solução para a má condição de saúde da população}

A origem dos kleingärten está intrinsecamente ligada ao processo de industrialização da Alemanha. Com o surgimento das grandes indústrias, nos séculos XVIII e XIX, a demanda de mão de obra operária fez com que a população urbana crescesse explosivamente, o que gerou um grande deficit habitacional. $\mathrm{Na}$ esteira da crescente urbanização, prevaleceu o tipo de edifício habitacional de ocupação máxima do terreno: três prédios paralelos germinados por uma ala transversal, em torno de dois pátios minúsculos - o mínimo obrigatório para o combate a incêndios. Apenas esses pátios ofereciam alguma luz, ar e sol. Em Berlim, desde então a maior concentração urbana do país, uma boa parte da população, na maioria famílias operárias, vivia em cortiços pouco salubres. Essa situação, no entanto, não se restringia aos

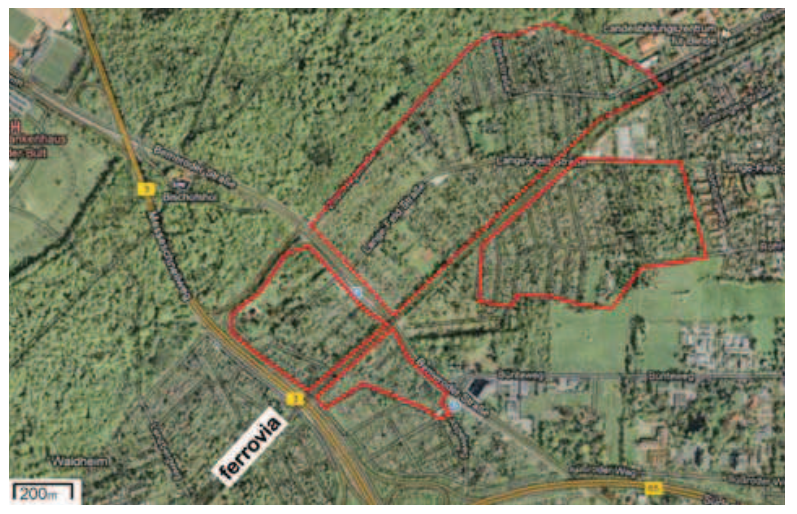

Figura 8 - Vista aérea do bairro Bishofshol em Hannover, onde às margens da ferrovia existem várias colônias

Fonte: GOOGLE MAPS (2011a).

Nota: A colônia demarcada pela linha pontilhada corresponde à área cuja construção vem sendo discutida.

\footnotetext{
7 Ver SPD-STADTVERBAND HANNOVER, 2011.
} 
operários dos grandes centros industriais. 0 mesmo se passou com mineiros na região do Ruhr e os trabalhadores do porto de Hamburgo (BMVBS, 2008).

Hähner-Rombach (2000) cita o exemplo do Estado de Baden-Würtenberg, no sudeste alemão, onde a proporção da população urbana aumentou de 24\%, em 1834, para 30\% em 1871, para 43\% em 1910 e para 54\% em 1939. 0 número de cidades aumentou apenas ligeiramente, de 132 em 1834 para 150 em 1939, ou seja, o aumento da população urbana ocorreu principalmente naquelas cidades já existentes.

Em virtude da poluição, do crescimento e adensamento rápidos, as cidades industriais se tornaram insalubres. Além disso, as condições nos locais de trabalho não eram melhores, o que colocava os trabalhadores em iminente risco de saúde. Nos bairros operários, em função dos baixos salários, da pobreza, da má nutrição, das precárias condições de higiene e da falta de insolação e ar fresco, imperavam as anomalias sociais. Essa população vivendo em condições precárias torna-se mais suscetível a doenças, principalmente às endêmicas, como a tuberculose. Aliás, a tuberculose, assim como outras doenças pulmonares, é considerada classicamente uma doença social (COSTA, 1988) e é um indicador da qualidade de vida. Na Alemanha, a tuberculose foi denominada de doença dos pobres (HÄHNERROMBACH, 2000), já que ela atingiu principalmente as classes menos abastadas. Na Inglaterra, segundo Costa (1988), a taxa de mortalidade por tuberculose foi muito alta em torno de 1650 , caindo então, lentamente, por muito tempo, até subir novamente - e de maneira explosiva - na primeira metade do século XIX, em decorrência da conhecida degradação do padrão de vida durante a revolução industrial.

Neste contexto, reivindicam-se cada vez mais veementemente espaços com luz, ar e sol. Assim, podemos dizer que a história "consciente" dos espaços verdes urbanos começa exatamente com a percepção de sua falta nas cidades, quando a bucólica paisagem rural foi transformada em uma paisagem urbana, altamente artificial e estéril. Naquele momento, os grandes defensores do verde urbano foram médicos sanitaristas, que lutavam por condições de habitação mais saudáveis para a população operária.
Na cidade de Magdeburg foi inaugurado, em 1828, o primeiro volksgarten ${ }^{8}$, um espaço público criado especificamente com o intuito de oferecer acesso à natureza e um espaço de recreação para a população operária. Algumas características dos volksgärten são: a malha viária simples, mas extensa, própria para longas caminhadas, e grandes áreas gramadas para a prática de exercícios físicos. Muitas vezes, esses exercícios eram organizados pelas próprias cidades ou, em alguns casos, pelas indústrias locais. Esses parques proliferaram em várias outras cidades. No entanto, com o mercado imobiliário aquecido e o elevado preço dos terrenos urbanos, se perpetuou a histórica escassez desses espaços nas áreas centrais adensadas. Quando existentes, trata-se de áreas remanescentes mais por motivos de pouca compatibilidade para uso para construções. Os primeiros parques foram normalmente instalados em áreas de valor do terreno mais baixo ou problemático, em razão da topografia, como zonas inundáveis ou longe das áreas habitacionais.

Para contornar a precária situação de alimentação, algumas famílias usavam terrenos baldios ou rurais, principalmente na periferia das cidades industriais, para plantar as suas verduras; a partir daí surgem as chamadas armengärten - hortas dos pobres (DRESCHER, 2001). Muitas dessas hortas eram irregulares e sujeitas a atos de vandalismo. Nesse período, viveu na cidade de Leipzig o médico Moritz Schreber (1808/1861), que se dedicou principalmente à saúde de crianças e adolescentes e às consequências sociais da vida urbana no início da industrialização.

Embora também conhecidos como schrebergärten, os kleingärten não foram criados pelo próprio Schreber, mas por iniciativa do Diretor Municipal da Educação de Leipzig, Ernst Innozenz Hauschild. Em 1864, ele torna realidade uma ideia de Schreber: criar um grande espaço, propício para as crianças brincarem e fazerem ginástica - tirando-as da rua e dando-lhes uma ocupação saudável ao ar livre. Esse espaço, que ele denominou de Praça Schreber (BDG, 2011), era na realidade um playground, onde as crianças podiam brincar sob adequada supervisão. Entenda-se aqui por brincar a prática ativa de exercícios, como corridas, corridas de saco, cabo de

\footnotetext{
${ }^{8}$ Literalmente jardim público, este Volksgarten Kosterberge representa a primeira área verde constituída pelo poder público na Alemanha. Pela primeira vez no país, um projeto desse tipo é planejado, construído e financiado por uma prefeitura. 0 desenho deste espaço, com 30 ha, leva a assinatura de Joseph Lenné (NEHRING, 1979).
} 
guerra etc. (STADT LEIPZIG, 2011a). Três anos mais tarde, para que as crianças aprendessem a assumir responsabilidades, apreciar e valorizar a natureza, foi implantado um canteiro - a princípio, somente com flores e plantas ornamentais. Esse canteiro é considerado a semente da qual a ideia dos kleingärten germinou.

A própria praça, porém, não teve vida longa. Já em 1876, ela teve que dar lugar a um empreendimento imobiliário. No mesmo ano, em uma área um pouco mais distante, foi criado um novo local para jogos infantis. Ao redor dele, desenvolveu-se a primeira colônia, que ainda hoje existe (Figura 9). Fazendo jus a este valor histórico, funciona aí, na sede da associação, a mesma fundada em 1864, um museu dedicado aos kleingärten (Kleingärtnermuseum) ${ }^{9}$. Essa primeira colônia era formada por famílias operárias, que, apoiadas pelo o sistema de arrendamento, gozavam de maior segurança e com treinamentos/ capacitações técnicas que asseguraram melhores colheitas e alimentos saudáveis e baratos.

Além do cultivo das próprias hortas, era também incentivada a criação de pequenos animais para suprir as famílias com um pouco de carne. Criar pombos, galinhas e coelhos nos kleingärten foi bastante comum até os anos 1950, quando a Alemanha se recupera da guerra e volta a ser uma

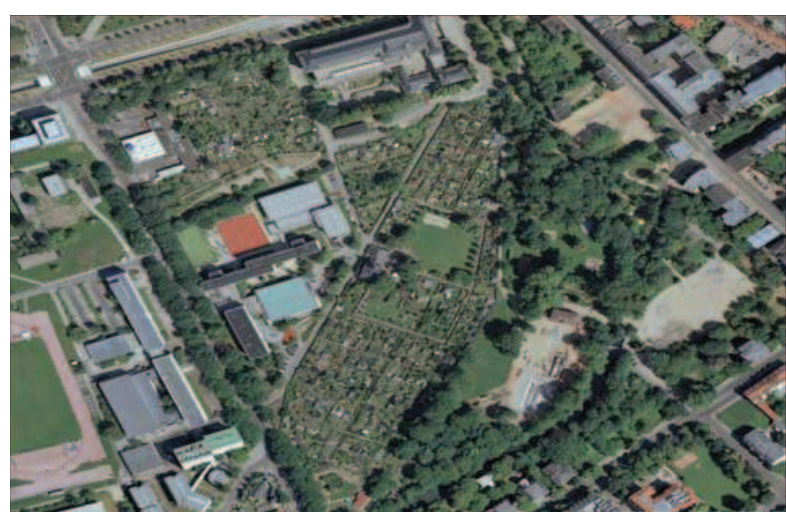

Figura 9 - Vista área da colônia "Dr. Schreber", na cidade de Leipzig, considerada a primeira Kleingartenkolonie

Fonte: GOOGLE MAPS, $2011 \mathrm{~b}$.

Nota: Em sua estrutura, pode-se perceber a área central comunitária, primeiramente usada para jogos e esportes - hoje como área para festas. potência industrial. Durante as guerras e nos perí odos que as seguiram, os kleingärten tiveram um papel crucial para assegurar o suprimento de alimentos para a população urbana. No período pós-guerra, Berlim chegou a contar com 200 mil parcelas. Hoje elas somam menos de 80 mil (BMVBS, 2008).

Como todo o processo de industrialização, na Alemanha ele também foi baseado na disponibilidade de mão de obra, na intensa exploração desta força de trabalho e no pagamento de baixos salários; porém, ao mesmo tempo, investimentos em educação e infraestrutura melhoraram a qualidade de vida da população. Comparada a outros países desenvolvidos, a Alemanha teve algumas particularidades no seu processo de industrialização. Desde cedo, o país adotou a política de "potência do bem-estar", com uma forte interferência do Estado na economia. Tal política, além de incentivar o desenvolvimento das técnicas de produção mediante a aplicação de recursos em pesquisas científicas, o que propiciou também as bases para criar um alto nível de instrução da população, se refletiu também em benefícios sociais para melhorar a renda da classe operária. Por meio dessa política, foram feitos investimentos em infraestrutura, como ferrovias, serviços postais e telegráficos, tão necessários para o transporte e a comercialização dos bens produzidos, mas que também trouxeram benefícios a todos.

\section{Benefícios - múltiplos e cumulativos}

Indubitavelmente, os kleingärten tornam as cidades e comunidades mais atraentes. Eles contribuem significativamente para torná-las menos opressivas ao arborizar áreas densamente construídas e altamente artificiais. Os kleingärten não são apenas uma adição valiosa à vegetação urbana, mas também o espaço cultural para muitas pessoas. Quando o primeiro kleingarten surgiu há mais de 200 anos, ele deveria permitir o livre acesso à natureza para aqueles que não podiam ter um jardim na sua casa (BDG, 2011). E essa ideia está sobrevivendo a todas as mudanças e tempos.

\footnotetext{
9 Ver DEUTSCHES KLEINGÄRTNERMUSEUM, 2011.
} 
É importante salientar que nem os kleingärten nem os jardins e quintais nas residências são um substituto para os espaços verdes públicos. Um estudo realizado na cidade de Dresden (SMANIOTTO COSTA et al., 2006) revelou que $90 \%$ das pessoas que têm oportunidade de estar ao ar livre dentro do seu próprio terreno usam os espaços verdes públicos com a mesma frequência que aqueles que não os têm. Assim, no sentido recreativo, social e psicológico, os jardins privados não têm o mesmo significado que os públicos.

Como outros espaços verdes, os kleingärten são reconhecidos por trazerem valiosas contribuições para o meio ambiente e para o bem-estar social no âmbito urbano. Essa variedade e multifuncionalidade significam que os kleingärten podem prover os mais variados benefícios de maneiras diversas a usuários diferentes e com resultados diversos. Como as áreas verdes urbanas, os kleingärten têm um papel importante em relação à qualidade de vida e um relevante papel na cultura dos alemães (GRÖNING, 2006).

Apenas para facilitar a compreensão na descrição mais detalhada destas funções e benefícios, abaixo é usada a classificação proposta pelo Projeto GreenKeys (2008). Essas funções e benefícios são selecionados entre aqueles ecológico-ambientais, sociais, econômicos e estruturantes. Evidentemente, esses benefícios e funções não podem ser vistos sob um aspecto único, já que os efeitos são cumulativos e múltiplos.

Com relação às funções ecológico-ambientais, os kleingärten assumem papel semelhante àquele de outros espaços verdes. Em geral, os kleingärten oferecem uma melhor qualidade de vida nas cidades pela arborização e estruturação do espaço construído; contribuem para o conforto ambiental e executam função compensatória em relação ao clima, temperatura e umidade do ar. Em virtude do baixo grau de impermeabilização do solo, eles têm um impacto positivo no balanço hídrico e na manutenção e melhoramento da qualidade do solo (SMANIOTTO COSTA, 2010). Esses dois últimos fatores são importantes na Alemanha, que sofre com os efeitos negativos de uma crescente modificação dos solos naturais e com sua compactação e impermeabilização ${ }^{10}$. Com grande proporção de áreas cobertas por vegetação, os kleingärten têm efeitos positivos na redução de ruído, fixação de poeira e filtragem do ar. Quando integrados à infraestrutura verde da cidade, pela conectividade de habitats, possibilitam a propagação e proteção de espécies e a preservação da biodiversidade. Por se tratar de áreas que contribuem para a permeabilidade dos espaços urbanos, têm efeitos climáticos, como o aumento da capacidade de infiltração de água, redução da erosão, resfriamento do ar e importante efeito para atenuar os efeitos das ilhas de calor. Além disso, na maioria dos kleingärten a compostagem e a reutilização da água da chuva já é uma prática corriqueira há bastante tempo.

Muitos autores consideram os kleingärten como áreas naturais dentro do ambiente urbano, aspecto com o qual o autor deste artigo não concorda, já que esses espaços, por sofrerem fortes alterações antropogênicas, não podem ser mais considerados espaços naturais. Ainda assim, a sua contribuição ambiental e suas funções psicológicas e recreativo-sociais permanecem inquestionáveis.

Se, por um lado, os kleingärten trazem vários benefícios ao ambiente urbano onde estão inseridos, por outro, o próprio espaço urbano é causa de problemas. Muitas vezes usados para conter a expansão urbana ou como zonas tampão, com o intuito de amenizar os efeitos negativos da urbanização, os próprios kleingärten ficam sujeitos à poluição. A poluição sonora, gerada principalmente pelo tráfego, é o problema mais comum, segundo estudo do BMVBS (2008). Talvez porque esse tipo de poluição seja mais facilmente percebido; mas outros estudos (STADT HANNOVER, 2004a; GALK, 2005) contestam a localização dos kleingärten, principalmente junto às rodovias, o que os torna mais suscetíveis a problemas como fuligem e gases. Outros problemas são consequências do clima urbano. Nas grandes cidades, por exemplo, em virtude das temperaturas mais altas e do ar mais seco, usa-se mais água que em cidades pequenas. Esses fatores criam um paradoxo: justamente os grandes centros urbanos e aquelas zonas mais densamente habitadas, pelo

\footnotetext{
${ }^{10} \mathrm{O}$ problema da transformação da paisagem para fins urbanos e da impermeabilização do solo é tão grave que o Governo Federal Alemão criou em 2003 uma estratégia nacional para remediá-lo. Em 2000, calculou-se que mais de 130 hectares de áreas naturais eram "consumidas" todos os dias. Isso corresponde a 180 campos de futebol e mais da metade desapareceu sob concreto ou asfalto - perdendo, com isso, todas as qualidades biológico-ambientais. 0 objetivo do governo federal é reduzir a taxa média diária para 30 ha até 2020. Ainda que a um ritmo de crescimento populacional negativo, o "consumo" da paisagem continua preocupante, e, embora já tenha baixado a 113 ha/dia em 2010, ainda é alto demais para atingir a meta (UMWELTBUNDESAMT, 2010).
} 
caráter preponderantemente artificializado de sua paisagem, são as que mais se beneficiam com os espaços verdes, mas são também aquelas que oferecem condições menos propícias.

0 mesmo estudo revelou que aproximadamente $2 \%$ dos kleingärten estão localizados em áreas consideradas com risco de contaminação do solo, por terem sido instalados em áreas industriais desativadas. Embora se trate de uma pequena parcela, o próprio estudo reclama que pouco ou quase nada vem sendo feito para minimizar tal situação, já que uma análise mais profunda do grau de contaminação e a remediação do solo seriam muito onerosos (BMVBS, 2008).

As funções sociais estão ligadas ao uso desses espaços pelos seres humanos, e incluem funções que estão intimamente relacionadas à possibilidade de lazer (ativo ou contemplativo) e aos benefícios psicológicos, educativos e culturais que os kleingärten proporcionam ao indivíduo e à coletividade. A psicologia nos ensina que para a saúde psíquica do homem é necessário um suficiente contato com a natureza (BARTON; PRETTY, 2010). Os kleingärten podem suprir o desejo de se estar num ambiente saudável e em contato direto com a natureza, em especial para aqueles que vivem em zonas urbanas densas (Figura 10). Essa oportunidade está aberta

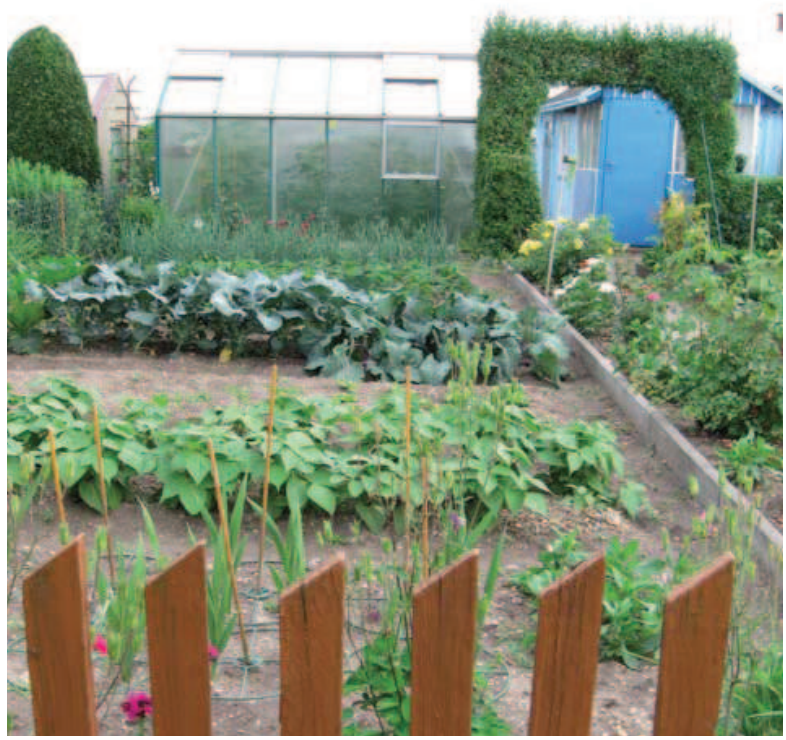

Figura 10 - Plantio de verduras e plantas ornamentais em uma parcela na cidade de Dresden

Foto: Barbara Schön (2011). basicamente a todas as pessoas, mesmo àquelas que não tenham renda alta ou que tenham dificuldades de locomoção. Muitas cidades oferecem auxílio financeiro à população de baixa renda para o arrendamento e manutenção de uma parcela. A preocupação social está ancorada nos princípios dos kleingärten, que protegem legalmente os menos abastados, seja pela limitação das taxas, ou pelos contratos de arrendamento (GALK, 2005).

As funções sociais devem ser analisadas segundo os beneficiários, já que as possibilidades de apropriação do espaço são diferentes. Embora semelhantes e complementares, existem aquelas que beneficiam diretamente o arrendatário e a sua família, e aquelas que beneficiam a população em geral.

Observando o arrendatário e suas famílias, vistos aqui como jardineiros e produtores dos próprios vegetais, os kleingärten oferecem uma oportunidade significativa para essa atividade de lazer e subsistência (Figura 11). Segundo Thimm (2011), trabalhar a terra nos ensina devoção, senso de dever, paciência e paixão. A sequência de atividades, tais como semear, observar o crescimento, o florescer e colher vegetais nos proporciona uma experiência pessoal saudável. Um jardineiro é um criador, é o senhor, ele determina o que e onde pode crescer. Pelo menos até que a própria natureza o puna e lhe

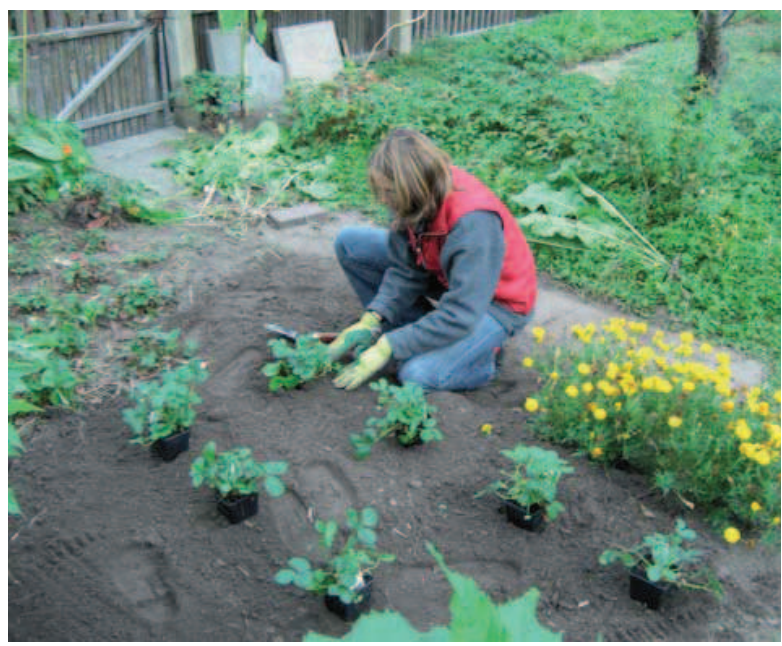

Figura 11 - Muitas famílias jovens estão descobrindo os kleingärten como uma fonte de alimentos seguros e como opç̃ó de lazer ativo e saudável

Foto: Lutz Reiter (2010). 
mostre os seus limites, por meio de plantas invasoras, ervas daninhas e parasitas.

Recentes estudos demonstram uma maior relação entre o espaço verde e a saúde (BARTON; PRETTY, 2010; BARTON; GRANT, 2006; SUNDBERG; SJÖSTRÖM, 2009). É cada vez mais evidente que a frequente utilização de espaços verdes melhora não só a nossa saúde física, mas também a mental. Esses estudos mostram que pessoas que têm na jardinagem uma atividade quotidiana sofrem menos de estresse. Atividades ao ar livre ajudam a reduzir os problemas associados à inatividade, obesidade e doenças crônicas. A jardinagem auxilia na redução da pressão arterial, a manter a frequência normal dos batimentos cardíacos e a relaxar os músculos. 0 simples fato de olhar uma planta sinaliza ao cérebro uma situação relaxante e de aconchego. Um jardim, segundo médicos e psicólogos, evoca uma experiência positiva de paz e ordem. Barton e Pretty (2010) demonstram que apenas cinco minutos por dia de atividade "verde", como jardinagem, caminhar, ou andar de bicicleta, melhoram o humor e aumentam a autoestima. 0 contato com a natureza pode levar a um melhor estado emocional e, a longo prazo, prevenir doenças (Figura 12).

Pela própria natureza, os kleingärten são estruturados com base na ideia de criar uma comunidade: arrendar uma parcela numa colônia significa querer fazer parte desta comunidade, o que fortalece a interação entre pessoas com interesses comuns. 0 estudo do BMVBS (2008) revelou que somente $20 \%$ dos arrendatários acham que os trabalhos comunitários são incômodos e lhes roubam

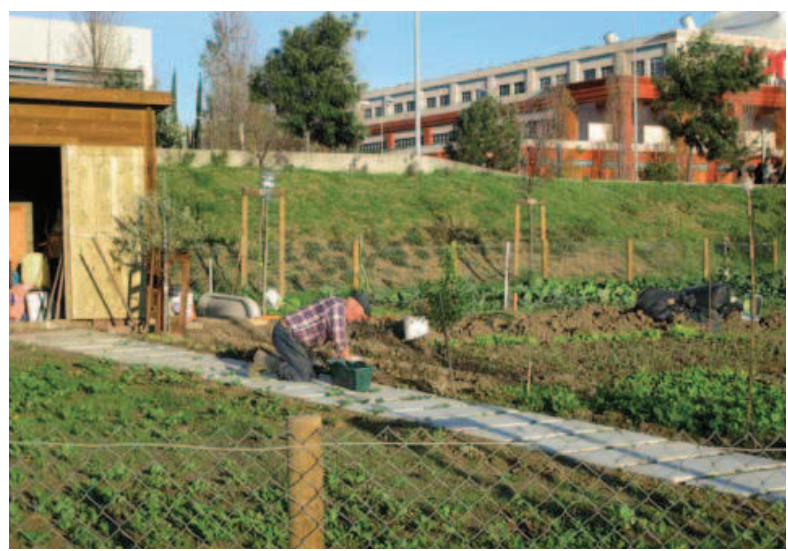

Figura 12 - Na horta comunitária do Parque Quinta das Granjas, em Lisboa, Portugal

Foto: Smaniotto Costa (2012). tempo demasiado. Assim, pode-se supor que os trabalhos comunitários são bem aceitos.

Em relação ao segundo grupo de beneficiários, a população em geral, observamos que as atividades mais comuns são caminhar ou passear e andar de bicicleta. Os kleingärten, como outras áreas verdes, também cumprem uma função educativa e estética ao oferecerem a oportunidade de contemplar a natureza e apreciar uma paisagem peculiar.

Os kleingärten são espaços integradores, para arrendatários e visitantes. Eles também podem funcionar como uma importante plataforma para o diálogo entre as gerações, para a integração de imigrantes e, especialmente para as famílias com crianças, eles têm um significado especial. Para crianças e adolescentes, os kleingärten oferecem oportunidades de diversão e espaços para comunicação: muitas vezes os kleingärten precisam compensar a falta de playgrounds, áreas para esportes inexistentes ou insuficientes nas zonas habitacionais.

Considerando a questão dos imigrantes, o estudo do BMVBS (2008) mostra, e Harbart (2011) confirma, que há uma mudança em relação à origem dos arrendatários: o número de imigrantes, principalmente vindos da Rússia, Turquia e outros países do leste europeu, que arrendam uma parcela vêm crescendo significativamente. Há, também, uma diferença no uso da parcela entre os alemães e os imigrantes. Enquanto os últimos as usam primordialmente para a produção de frutas e verduras, os alemães as usam mais para o lazer e, consequentemente, nas suas parcelas a proporção de plantas ornamentais é maior.

Por meio de outras atividades, não somente dirigidas aos membros da colônia, muitos kleingärten procuram contato com a comunidade dos bairros próximos ou com instituições sociais. Em particular, muitos kleingärten mantêm estreito contato com jardins de infância e escolas. Muitas colônias, usando as áreas comuns ou as parcelas não arrendadas, criam espaços interessantes como biótipos, lagos, áreas úmidas ou jardins especiais, por exemplo, com plantas medicinais, jardins para deficientes visuais, ou oferecem a essas instituições espaço para a instalação de hortas escolares.

Por sua manifestação histórica e seus benefícios urbanos e ambientais, mas também por ser um tipo de atividade recreativa exercida por uma boa parte da população do país, o movimento Kleingärten se 
tornou um importante componente da cultura alemã. Para valorizar este fato foi até criado um museu que funciona num lugar histórico - onde surgiu a primeira colônia na cidade de Leipzig ${ }^{11}$ (Figura 9).

Enquanto os benefícios ecológicos e sociais dos espaços verdes vêm sendo bem estudados, o seu valor econômico tem sido alvo de muito pouca pesquisa ou, quando examinado, é limitado a determinados aspectos. Isso torna os benefícios econômicos difíceis de serem quantificados e, principalmente, de serem usados como argumentos políticos ou urbanístico-ambientais. A falta de evidências fundadas nos leva a confiar em suposições. Essas lacunas são também consideradas razões que levam ao não reconhecimento dos espaços verdes em sua plenitude econômica, principalmente pela classe política e por empreendedores imobiliários (GREENKEYS, 2008).

Essa afirmação pode ser ilustrada com outro exemplo. Em 2003, no âmbito do Projeto URGE ${ }^{12}$, foi feita uma análise da situação dos espaços verdes em 15 cidades europeias. Ela mostrou que os benefícios ecológicos e, especialmente, as funções sociais das áreas verdes, que já foram objetos de extensa pesquisa, são amplamente considerados na prática, enquanto o benefício econômico, pouco conhecido, em muitas cidades nem é levado em consideração.

Embora, como todos os outros espaços verdes, os kleingärten sejam normalmente entendidos como um fator de custo principalmente no que se refere a gastos com sua manutenção, eles trazem imensos benefícios econômicos para as comunidades e cidades, tais como as diversas empresas que atuam no setor de jardinagens e afins; a gama vai desde viveiros artesanais às grandes indústrias, significando centenas de empregos. Assim, eles oferecem um campo de trabalho, desde mão de obra especializada (urbanistas e paisagistas) até a menos qualificada.

Uma vez que os benefícios econômicos não são gerados diretamente, eles são originados por uma multiplicidade de fatores, que não podem ser "medidos" sob um único aspecto. Uma abordagem monofuncional não é, portanto, razoável ou viável. Isso faz com que esses benefícios sejam também de difícil interpretação. Nenhum espaço verde é implantado especificamente para gerar um lucro monetário. Quase como um efeito colateral, porém positivo, esse espaço valoriza o seu entorno. Ele gera um benefício econômico agregado. Um kleingarten, como já visto, pode melhorar a saúde física dos arrendatários e de suas famílias, gerando consequentemente economia para o orçamento familiar, já que reduzirá gastos com médicos e remédios. Os seguros de saúde também ganham, já que este segurado usará menos os seus serviços. 0 mesmo acontece com as melhorias ambientais, que fazem com que as cidades acabem gastando menos na solução de problemas e na reparação de danos ambientais.

Neste contexto, os kleingärten, como todo espaço verde, têm um relevante papel na percepção da qualidade urbana. Na acirrada concorrência entre as cidades europeias, este pode ser um fator determinante: as cidades "verdes" podem atrair mais empresas, indústrias e mão de obra especializada.

Talvez o fator mais importante da valorização que estes espaços proporcionam, pelo diferencial que ele pode significar para a implantação de novos empreendimentos imobiliários, seja o fato que a mera proximidade de um espaço verde já cause um aumento no valor das propriedades vizinhas, influenciando também o preço dos aluguéis. Estudos incipientes mostram que neste campo ainda há muito a ser investigado, mas a pouca evidência existente revela dados importantes. Um estudo realizado em Berlim (LUTHER et al., 2002) prova que $20 \%$ do valor de um aluguel, bem como o valor de um terreno, estão ligados diretamente à existência e à qualidade dos espaços verdes em um raio de 600 metros. Considerado um "bom endereço", quanto melhor for a qualidade ambiental e as oportunidades de recreação próximas, maior é a influência destes espaços no valor do imóvel ou no de seu aluguel. 0 mesmo estudo revela que a qualidade da vizinhança onde se encontra o imóvel é fator relevante para $85 \%$ dos entrevistados na decisão por alugar ou comprar imóvel num determinado bairro, quer para uso residencial, quer para uso comercial.

\footnotetext{
${ }^{11}$ Ver DEUTSCHES KLEINGÄRTNERMUSEUM, 2011.

${ }^{12}$ Disponível em: <http://www.urge-project.ufz.de>. Acesso em: 12 maio 2011.
} 
Os kleingärten podem também ser um fator turístico, como é o caso de Leipzig ou Nærum ${ }^{13}$ (Figuras 13 e 14). Pela sua linguagem arquitetônica

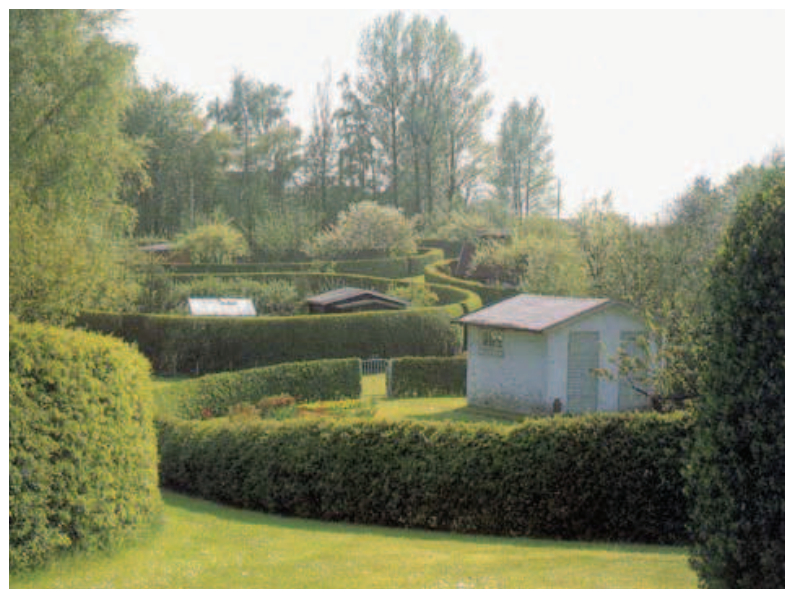

Figura 13 - Carl Theodor Sorensen (1893-1979), um dos grandes paisagistas do século XX, criou em 1948 na cidade de Nærum (Dinamarca) uma Kleingartenkolonie peculiar e que se tornou uma de suas mais importantes obras

Fonte: ANDERSSON; HOYER, 1993.

Nota: Ao todo, são 40 parcelas ovais, formadas por cercas vivas e distribuídas aleatoriamente sobre 0 "tapete verde", a área gramada de uso comum. A colônia está situada perto de um grande conjunto de habitaç̃oes sociais, Nærumvænge, com apartamentos e casas geminadas, caracterizados por sua arquitetura uniforme e homogênea.

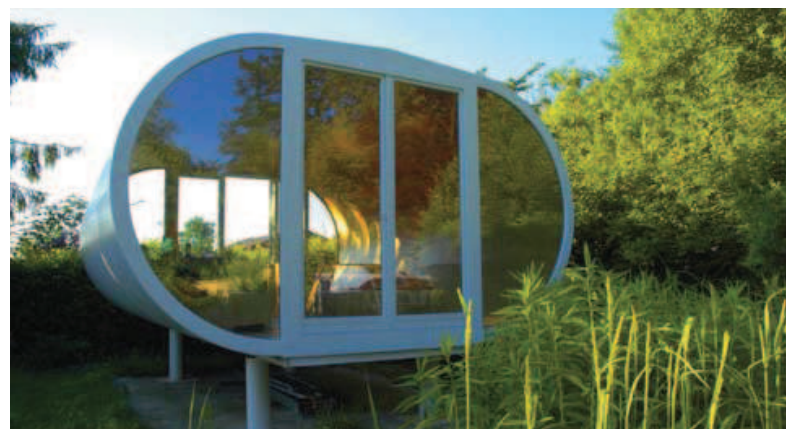

Figura 14 - Com frequência, arquitetos e designers se debruçam sobre os kleingärten e contribuem com ideias interessantes, mas estas nem sempre são bem aceitas pelas colônias mais tradicionais

Foto: Lothar Mattejat (2010).

Nota: Aqui, o artista Lothar Mattejat, de Hamburgo, criou o seu próprio gazebo. 0 próprio artista relata que os vizinhos tiveram que se acostumar a essa obra curiosa ${ }^{14}$. e valor estético, essas colônias atraem muitos visitantes. Isso não traz somente vantagens para o comércio local, mas também prestígio para a cidade e, no caso de Nærum, até para o órgão dinamarquês gestor do patrimônio cultural. Mesmo que os espaços verdes nem sempre representem o alvo direto do turista, estes desempenham um papel importante nas estratégias de marketing da indústria do turismo.

A função estruturante se refere ao uso dos kleingärten na organização e na composição da malha urbana. Como outro tipo de uso do solo, os kleingärten contribuem para definir a estrutura urbana, dando-lhe forma e conteúdo. Cuidar bem do grande patrimônio em espaços livres e áreas verdes é um dos diferenciais que caracterizam as cidades da Europa Central. Assim como as exposições de paisagismo (SMANIOTTO COSTA, 2008), as cidades usam esses espaços para estruturar o tecido urbano e criar uma infraestrutura verde, garantindo uma contiguidade maior. A somatória de espaços diferenciados se traduz em benefícios mais amplos às condições ambientais das cidades e à qualidade de vida da população.

Como um elemento da paisagem urbana, os kleingärten permitem a legibilidade do espaço, quebram a monotonia, tornando essa paisagem mais rica e diversificada, como demonstra o mais novo parque de Lisboa (Figura 15). Essa função estética, com a inclusão de diferentes tipos de verde e elementos paisagísticos, contribui para a valorização visual da cidade. Os kleingärten também podem se transformar em ponto de identificação, bem como marcar o caráter e a imagem de um bairro ou de uma cidade.

Muitas vezes, os kleingärten são usados como "mediadores" entre diversos usos urbanos, principalmente quando há conflitos, por exemplo, entre uma zona industrial e uma residencial. Em Hannover, são usados como zona tampão entre o espaço rural e o urbano, fazendo com que haja menos conflitos e interferências. A Figura 6 evidencia esse fato, mostrando como os kleingärten estão distribuídos quase de forma radial ao centro urbano.

\footnotetext{
${ }^{13}$ Outras imagens podem ser vistas em: BARBEY, T. Naerum allotment gardens by Carl Theodor Sorensen, Denmark 1952. Disponível em: <http://www.vulgare.net/naerum-allotment-gardens-by-carl-theodor-sorensen-denmark-1952>. Acesso em: 21 jul. 2011.

${ }^{14}$ Outros exemplos podem ser vistos em: Hille, Nils. Gartenhaus ohne Graus. Disponível em: <http://www.dabonline.de/2008-05/ gartenhaus-ohne-graus>. Acesso em: 22 maio 2011.
} 


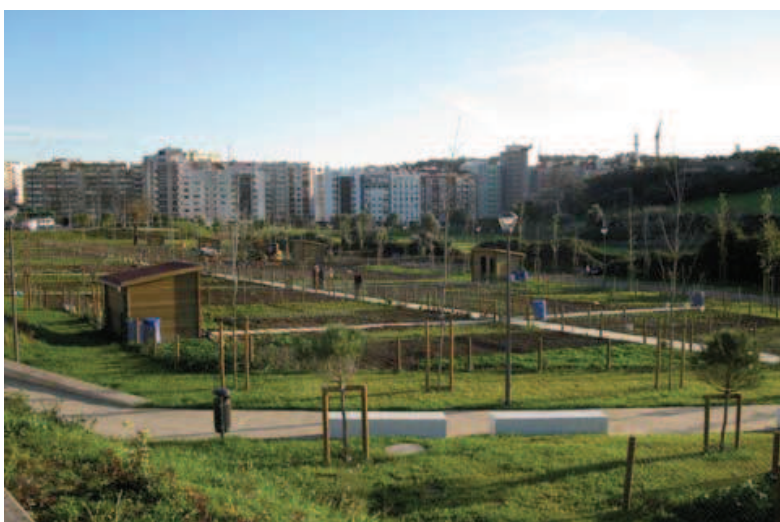

Figura 15 - Em Lisboa está sendo instituúdo o primeiro conjunto de hortas organizado de forma semelhante aos kleingärten

Foto: Smaniotto Costa (2012).

Nota: Quando da inauguracãão da $2^{a}$ fase da obra do Parque Urbano da Quinta da Grania, em outubro de 2011, foi entregue a primeira bateria de kleingärten. Esse Parque, além de conter equipamentos recreativos, é caracterizado pela existência de uma bacia de retenção, a qual permite sua utilizacão como área de lazer informal. Interessante aqui e a inserção dessas hortas como um complemento de um parque urbano.

\section{Considerações finais}

Em função da grande preocupação com a saúde ambiental, a Alemanha hoje é uma referência mundial. 0 país se vê diante de um alto índice de conscientização ecológica em todas as camadas da população, e isso também se reflete na qualidade de vida que as cidades oferecem a seus habitantes. Um critério comumente usado para quantificar essa qualidade de vida é a proporção de espaços verdes e a qualidade da paisagem urbana. $\mathrm{E}$ as cidades alemãs são, em geral, ricas não só em espaços, mas também em diversidade, estruturas e qualidade dentro dos tecidos urbanos.

Os kleingärten, como um sistema de objetivos, normas e padrões, surgiram na Alemanha com a intenção de propiciar segurança alimentar e uma opção de lazer. E contribuíram para melhorar a qualidade de vida de uma grande parte da população urbana, desprivilegiada e pobre, numa época em que ainda nem se pensava em justiça ou igualdade social no discurso político.

Neste contexto, pela sua dimensão, os kleingärten assumem um importante papel na composição da infraestrutura verde, além de prestarem à função social um significado muito mais abrangente ao oferecerem a todos os cidadãos, de todas as classes sociais, a oportunidade para a prática de jardinagem e para se dedicarem a um lazer ativo e atraente, baseado no contato com a natureza.

Pelos seus estatutos, as associações de kleingärten influenciam a forma e o uso de cada parcela e, portanto, servem também para moldar a consciência ecológica e a preocupação com a natureza de cada arrendatário. As oportunidades de educação e treinamento oferecidas também servem para questionar a própria atitude perante o meio ambiente, talvez o fator mais importante para se ganhar a cumplicidade da população.

As cidades se transformam; algumas crescem, outras encolhem. Algumas passam pelo processo de desenvolvimento racionalmente, enquanto outras, pela ausência de planejamento, controle e interesse político, o fazem sem priorizar a qualidade ambiental. 0 desconhecimento e a falta de informação já não podem ser mais usados como argumento. 0 mundo globalizado e a era da internet trazem as vantagens da informação imediata, de se poder conhecer virtualmente outros lugares e observar outras situações. Conhecer exemplos de outros países, mesmo com experiências e pontos de partida diferentes, nos fornece um excelente instrumento para avaliar a própria situação.

Este trabalho não questiona se a experiência alemã com os kleingärten pode ser um exemplo para o nosso país. Embora exista potencial, já que aqui há também a necessidade de reduzir as taxas de pobreza e melhorar as condições de lazer da população (fora dos shoppings), este estudo tem a intenção de discursar sobre uma experiência interessante, proporcionando a possibilidade de se abrir novos horizontes.

0 reconhecimento das funções e valores das áreas verdes não significa, entretanto, que o desenvolvimento do verde urbano goze de uma posição privilegiada na agenda política. A batalha pela qualidade ambiental das cidades tem que ser ganha todo dia.

\section{Referências}

ANDERSSON, S.-I.; HØYER, S. C. Th. Sørensen: En Havekunstner. Copenhagen: Arkitektens Forlag, 1993. 
BARTON, H.; GRANT, M. A health map for the local human habitat. Journal of the Royal Society for the Promotion of Public Health, v. 6, n. 126, p. 252-261, 2006.

BARTON, J.; PRETTY, J. What is the best dose of nature and green exercise for improving mental health? A multistudy analysis. Environmental Science \& Technology, n. 44, v. 10, p. 3947-3955, 2010.

BUNDESMINISTERIUM DER JUSTIZ - BMJ. Baugesetzbuch. 2011a. Disponível em: <http://www.gesetze-im-internet.de/bbaug/index.html>. Acesso em: 17 jul. 2011.

BUNDESMINISTERIUM DER JUSTIZ - BMJ. Bundeskleingartengesetzt. 2011b. Disponível em: <http://www.gesetze-im-internet.de/bkleingg/index.html>. Acesso em: 17 jul. 2011.

BUNDESMINISTERIUM FÜR VERKEHR, BAU UND STADTENTWICKLUNG - BMVBS. Städtebauliche, soziale und ökologische Bedeutung des Kleingartenwesens. Berlin: BMVBS, 2008.

BUNDESVERBAND DEUTSCHER GARTENFREUNDE BDG. Für eine bessere Zukunf. 2011. Disponível em: <http://www.kleingarten-bund.de>. Acesso em: 22 jun. 2011.

COSTA, D. C. Comentários sobre a tendência secular da tuberculose. Cadernos de Saúde Pública, v. 4, n. 4, p. 398406,out./dez.1988.Disponívelem:<http://www.scielo.br/ scielo.php?pid=S0102-311X1988000400005\&script=sci arttext>. Acesso em: 13 jan. 2012.

DEUTSCHES KLEINGÄRTNERMUSEUM. Das Museum. 2011. Disponível em: <http://www.kleingarten-museum. de>. Acesso em: 4 jul. 2011.

DIE STÄNDIGE KONFERENZ DER GARTENAMTSLEITER BEIM DEUTSCHEN STÄDTETAG - GALK. Kleingärten im Städtebau. Köln: GALK, 2005.

DRESCHER, A. Allotment gardens and other urban agriculture in Germany. In: SUB-REGIONAL EXPERT MEETING ON URBAN HORTICULTURE, 1., 2001, Stellenbosch. Proceedings... Stellenbosch: FAO; University of Stellenbosch, 2001.

GREENKEYS. GreenKeys @ your city: a guide for urban green quality. Dresden: IOER, 2008. Disponível em: <www.greenkeys-project.net>. Acesso em: 13 jan. 2012.
GRÖNING, G. Aspectos da cultura do jardim e do desenvolvimento dos espaços livres na Alemanha. RA'E GA: 0 espaço geográfico em análise, v. 11, p. 143-170, 2006.

HÄHNER-ROMBACH, S. Sozialgeschichte der Tuberkulose: Medizin, Gesellschaft und Geschichte. Stuttgart: Franz Steiner Verlag, 2000.

HARBART, F. Der parzielle Ärger mit den Kleingärten in Hannover. Hannoversche Allgemeine, p. 15, 20 jul. 2011. Disponível em: <http://www.haz.de/Hannover/Ausder-Stadt/Uebersicht/Der-parzielle-Aerger-mit-denKleingaerten-in-Hannover>. Acesso em: 22 jul. 2011.

LUTHER, M.; GRUHN, D.; KUNNEWEG, H. Die Bedeutung von Freiräume und Grünflächen für den Wert von Grundstücken und Immobilien. Berlim: TU Berlin, 2002.

NEHRING, D. Die Geschichte des Stadtgrüns. Hannover: Platzer Verlag, 1979. v. 4.

OFFICE INTERNATIONAL DU COIN DE TERRE ET DES JARDINS FAMILIAUX. Bindestrich: Verbandsnachrichten. 2011. Disponível em: <www.jardins-familiaux.org>. Acesso em: 12 jul. 2011.

SMANIOTTO COSTA, C. O verde como propulsor do desenvolvimento urbano: exemplos das exposições de paisagismo na Alemanha. Malha Urbana: Revista Lusófona de Urbanismo, v. 6, n. 6, p. 1-21, jan./dez. 2008.

SMANIOTTO COSTA, C. Áreas verdes: um elemento chave para a sustentabilidade urbana - A abordagem do Projeto GreenKeys. Arquitextos, ano 11, n. 126, nov. 2010. Disponível em: <http://www.vitruvius.com.br/revistas/read/arquitextos/10.126/3672>. Acesso em: 12 jul. 2011.

SMANIOTTO COSTA, C.; SCHERZER, C.; SUTTER-SCHURR, H. Tage im Grün: Nutzerwünsche und Nutzungsverhalten im öffentlichen Freiraum - eine Untersuchung in Dresden. Stadt und Grün, n. 11, p. 12-19, nov. 2006.

SOZIALDEMOKRATISCHE PARTEI DEUTSCHLANDS SPD-STADTVERBAND HANNOVER. SPD vor Ort: Besuch beim Bezirksverband der Kleingärtner. 2011. Disponível em: <http://www.spd-hannover-stadt.de/aktuell/nachrichten/2011/331889.php>. Acesso em: 12 jul. 2011.

STADT DRESDEN. Themenstadtplan. 2012. Disponível em: <http://stadtplan.dresden.de>. Acesso em: 13 jun. 2011 
STADT HAMBURG. Kleingärten mit Zukunft - Lebenswerte Stadt. Dokumentation Kongress, 11 Mai 2007. Hamburg: Behörde für Stadtentwicklung und Umwelt, 2007.

STADT HANNOVER. Fachbereich Umwelt und Stadtgrün. Kleingärten in Hannover. 2004a. Disponível em: <http://www.hannover.de/de/umwelt_bauen/umwelt/ nah_park/naherh/klgakult/datfakkl.html>. Acesso em: 17 jul. 2011.

STADT HANNOVER. Gartenverordnung Hannover. Hannover: Stadt Hannover, 2004b.

STADT LEIPZIG. Der erste Schreberplatz. 2011a. Disponível em: <http://www.leipzig-lexikon.de/WALDFLUR/ swv1.htm>. Acesso em: 19 jul. 2011.

STADT LEIPZIG. Kleingartenanlagen - Erholungsräume - Spielräume - Lebensräume - Kontakträume. 2011b. Disponível em: <http://www.leipzig.de/de/buerger/freizeit/leipzig/kleingaerten/index.shtml>. Acesso em: 18 ago. 2011
STATISTISCHES BUNDESAMT DEUTSCHLAND. Bevölkerungsstand. 2010. Disponível em: <http://www.destatis.de>. Acesso em: 13 jun. 2011.

SUNDBERG, C. J.; SJÖSTRÖM, M. Improve your health with exercise. Medical Science, p. 6-8, 2009. Disponível em: <http://ki.se/content/1/c4/04/13/MedicalScience09. pdf $>$. Acesso em: 13 jul. 2011.

THIMM, von K. Jeder ein lieber Gott. Der Spiegel, n. 23, p. 118-120, Juni 2011. Disponível em: <http://www.spiegel.de/spiegel/print/d-78832479.html>. Acesso em: 13 jul. 2011.

UMWELTBUNDESAMT. Sustainable construction and housing: a need based approach for the future. Dessau: Umweltbundesamt, 2010.

Recebido: 04/08/2011 Received: 08/04/2011

Aprovado: 31/01/2012 Approved: 01/31/2012 